\title{
Stagnacja, ewolucja czy rewolucja. Ustrój Polski między 13 grudnia 1981 a 4 czerwca 1989 r. Mity i fakty ${ }^{1}$
}

$\mathbf{W}$ dziejach na szczęście dla ludzkości znacznie częściej możemy mówić o przemianach ewolucyjnych niż o rewolucjach, które oznaczały zmiany gwałtowne, nie zawsze o pozytywnym wydźwięku ale za to często pociągające za sobą krwawe ofiary. Propagandyści, niekiedy z tytułami naukowymi, chętniej jednak piszą o tych drugich niż o pierwszych, unikają posługiwania się pojęciem synkretyzm. Posługują się nim różne dyscypliny, m.in. biologia, psychologia i nauki społeczne, w których używane jest zamiennie z takimi pojęciami, jak akomodacja, akulturacja czy asymilacja. Nas interesuje tu ono z punktu widzenia kultury politycznej na ewolucję ustrojową w Polsce lat 1980-1990.

Historyk potrzebuje dystansu czasowego, by ocenić wydarzenia z najnowszych dziejów. Ich głównych aktorów oraz trwałość dokonań z reguły może ocenić bowiem bez emocjonalnego zaangażowania dopiero wówczas, gdy odpłyną łodzią Charona na drugą stronę rzeki Styks. Spojrzenie w przeszłość pozwala jednak stwierdzić, że to nie wystarcza i niekiedy ataki na daną postać nasilają się również po zejściu ze świata, jak to miało miejsce w wypadku Józefa Piłsudskiego. Ze względu na jego rolę dziejową wzbudzał od początku zainteresowanie badaczy, przy czym początkowo dominowała hagiografia (a z drugiej strony dosyć ostra - choć tłumiona, niekiedy brutalnie, przez władze krytyka) ${ }^{2}$, która po drugiej wojnie światowej znalazła kontynuację na emigracji przy zasłonie milczenia w kraju, w zasadzie aż po rok 1980, choć po przełomie październikowym 1956 r. była ostrożnie uchylana ${ }^{3}$.

\footnotetext{
${ }^{1}$ Referat w skróconej wersji został wygłoszony dnia 22 maja 2009 r. na zorganizowanej przez Zakład Systemów Politycznych Wydziału Nauk Politycznych i Dziennikarstwa Uniwersytetu Adama Mickiewicza w Poznaniu konferencji naukowej „Ewolucja systemu wyborczego w Polsce”.

${ }^{2}$ Zob. W. Wójcik, Józef Piłsudski, w: Życiorysy historyczne, literackie i legendarne, pod red. Z. Stefanowskiej, J. Tazbira, Seria II, Warszawa 1989, s. 303-346; idem, Nadzieje i złudzenia. Legenda Pitsudskiego w polskiej literaturze międzywojennej, Katowice 1978; D. i T. Nałęczowie, Józef Piłsudski-legendy i fakty, Warszawa 1986. W pierwszych latach po zakończeniu drugiej wojny światowej do nielicznych pozytywnych wyjątków należał sprzeciwiający się propagadnowym atakom na Marszałka profesor Henryk Jabłoński, Z dziejów obozu legionowo-peowiackiego, „Dzieje Najnowsze” 1947, nr 1. Jego uczniem był najwybitniejszy monografista Marszałka, Andrzej Garlicki (zob. przypis następny).

${ }^{3}$ Obszerny artykuł, wszechstronnie naświetlający życie i działalność tej wybitnej acz kontrowersyjnej postaci, ukazał się w fundamentalnym wydawnictwie naukowym na dziewięć lat przed zniesieniem cenzury: A. Garlicki, Józef Pitsudski, w: Polski Słownik Biograficzny, t. XXVI, Wrocław 1981, s. 311-324. Oparty on został na gruntownie udokumentowanej monografii pióra tegoż autora, która zapewne by nie kłuć w oczy nazwiskiem jej bohatera na karcie tytułowej, została opublikowana w postaci trylogii: Uźródeł obozu belwederskiego (Warszawa 1978), Przewrót ma-
} 
Głosy krytyki po 1935 r. miały swe uzasadnienie w sytuacji, że wprawdzie zabrakło wodza ale pozostali epigoni, wyrośli w cieniu jego legendy i sprawujący nadal (czyli w latach 1935-1939) władzę w Drugiej Rzeczypospolitej. Propagowały one zdecydowanie kult jednostki i z takim zafałszowanym jednostronnie obrazem była podejmowana przez opozycję polemika wokół postaci zmarłego wodza. On sam był mistrzem manipulacji opinią publiczną ale trzeba od razu zauważyć, że czynił to w sposób inteligentny, posiadał znaczną erudycję i dobrze władał piórem - sam pisał swoje teksty, które stanowić mogą kapitalne źródło nie tylko dla historyka, ale również - między innymi - dla językoznawcy czy psychologa polityki. Opublikowane w jedenastu tomach po jego śmierci, są dziś łatwo dostępne dzięki reprintowi sprzed ćwierćwiecza ${ }^{4}$.

Jeśli tu zwracamy uwagę na dzieje prawdy i legendy o czołowym mężu stanu okresu międzywojennego, a więc zamkniętej choć nadal budzącej emocje epoki - to dlatego, by wskazać potrzebę zajęcia się przez naukę nie pozostającą na usługach propagandy biografiami przywódców z okresu najnowszej transformacji czyli ostatniego trzydziestolecia ${ }^{5}$.

Modelowym przykładem postaci sprawiających kłopoty tym wszystkim, którzy z potrzeby propagandowej wynoszą je do rzędu bohaterów, jest dziś Lech Wałęsa - jego stworzoną w określonych warunkach historycznych legendę niszczą zarówno przeciwnicy polityczni,

jowy (1981) oraz Od maja do Brześcia (1981). W zmienionych warunkach politycznych znaczny nakład osiaggnęła przeznaczona dla szerokich kręgów bogato ilustrowana publikacja, której głównym bohaterem jest właśnie ta najwybitniejsza postać Polski międzywojennej: Prosto z Wiejskiej. Sejm i Senat II Rzeczypospolitej w karykaturze i satyrze, wyboru dokonał i szkicami poprzedził A. Zakrzewski, Wrocław-Warszawa-Kraków 1990.

4 Odsyłamy tu do studiów pod redakcją Marka Jabłonowskiego i Elżbiety Kossewskiej: Piłsudski na łamach i w opiniach prasy polskiej 1918-1989, Warszawa 2005. Redaktorzy naukowi piszą we wstępie: Piłsudski doceniat wage prasy i szczególnq pozycję dziennikarzy w życiu politycznym i społecznym. Oni z kolei przez całe dziesięciolecia okazywali niesłabnace zainteresowanie osobq Marszałka, także po 1935 roku. Wiedza o tym, jak byt postrzegany i opisywany przez publicystów, pisarzy, wspótpracowników, admiratorów i przeciwników jest stosunkowo niewielka, zwłaszcza gdy porównamy ja z badaniami poświęconymi jego wizerunkowi jako polityka czy wojskowego (s. 9).

${ }^{5}$ Do publikacji, zwłaszcza prasowych, trzeba podchodzić z ostrożnością, czytelnik bezkrytyczny bierze za dobrą monetę każdy - zwłaszcza odpowiadający jego wyobrażeniom - tekst. Dotyczy to nawet ...nekrologów. Oto przykład: w „Gazecie Wyborczej” z 22 sierpnia 2009 r. (mutacja: Poznań, s. 15) ukazał się takowy, sygnowany przez Wielkie Przeoraty Orderu św. Stanisława w Polsce i na świecie oraz Władze i Członków Orderu św. Stanisława, z informacją, że w dniu 17 sierpnia po ciężkiej chorobie zmarł Juliusz ksiażę Nowina Sokolnicki, Prezydent Rzeczypospolitej Polskiej na Uchodźstwie. Ceniony i szanowany polityk, działacz społeczny, wielki Polak, Kawaler Orderu Orła Białego, Wielki Mistrz Orderu św. Stanisława... Ktoś średnio zorientowany w zawiłościach londyńskiej emigracji może zapytać o ową prezydenturę, skoro z takąż godnością występował jako ostatni Ryszard Kaczorowski, którego jako swego poprzednika potraktował L. Wałęsa, mało kto jednak rozeznaje się w kwestiach schizmy na „najwyższym urzędzie” RP nad Tamizą, o której głównym bohaterze autor ostatniego tomu wielkiej syntezy przygotowanej na Uniwersytecie Jagiellońskim napisał: Pewne, raczej kuriozalne, znaczenie w środowisku emigracyjnym posiadal [...] ośrodek skupiony wokót samozwańczego prezydenta RP Juliusza Nowiny-Sokolnickiego, urzędujacego do 1990 r. Twierdził on, że jest legalnie mianowanym następca prezydenta Zaleskiego [August, zm. 1972 - MK]. Jego działalność w istocie ośmieszała ideały , legalizmu”. Awansował bowiem bez opamiętania kombatantów na wyższe stopnie wojskowe, mianował nawet marszałka Polski (któż słyszał o owym Antonim Zdrojewskim, generale?), orderem Orła Białego uhonorował Lecha Wałęsę i prałata Henryka Jankowskiego, którego uczynił również ...kontradmirałem (ów kapłan wśród wieku innych epatował również insygniami tego dostojeństwa!) - zob. A. L. Sowa, Od drugiej do trzeciej Rzeczypospolitej (1945-2001), w: Wielka historia Polski, t. 10, Kraków 2001, s. 275. Użytkownik tej syntezy posiada stosowne rozeznanie co do rzeczywistej roli osoby tak pięknie ocenionej w nekrologu, typowy jednak czytelnik „Gazety Wyborczej" otrzymuje tu ładunek fałszywych informacji. Nekrologi to też źródło dla badacza, przy tym odpowiadające rzymskiej maksymie: de mortuis aut nihil, aut bene. 
jak i on sam. Obserwując jego zaskakujący flirt z wysoce podejrzanym ugrupowaniem o pięknej nazwie Libertas (,Wolność”) nie wiemy, czym się on w skali krajowej i międzynarodowej zakończy ${ }^{6}$. Na tym miejscu można natomiast skonstatować, że legenda tej postaci w przyszłości, kiedy bez gniewnego zaangażowania będzie można o niej pisać, to temat wdzięczny dla biografisty, a także dla badacza współczesnej kultury politycznej w Polsce.

Wymodelowany przez propagandę obraz Wałęsy stworzył typową legendę pozytywną ${ }^{7}$, podczas gdy na przeciwległym biegunie postawiła ona postać Wojciecha Jaruzelskiego, ukazywanego w czarnej legendzie, w sposób również sprymitywizowany, z lekceważeniem dla faktów źródłowych.

W szerszej skali spojrzenie na najnowsze dzieje i przeobrażenia przełomu XX i XXI wieku prowadzi do wniosku, że nihil novi sub sole, nic nowego pod słońcem: zwycięzcy biorą wszystko, usiłują też zawłaszczać osiagnnięcia czasu transformacji ustrojowej. Najlepszy tego dowód daje sprawa obchodów dwudziestolecia doniosłych wydarzeń z roku 1989 - na zorganizowane w sejmie przez lewicę spotkanie dla upamiętnienia Okrągłego Stołu nie zdołała przybyć reprezentacja rządzącej Platformy Obywatelskiej, nie mówiąc o „czwartej brygadzie" nazywającej się patriotyczną prawicą; obecni byli - obok pierwszego prezydenta odrodzonej po 1989 r. Rzeczypospolitej, którą konsekwentnie nazywam IV, jeśli już tak chcemy numeracji - autentyczni współuczestnicy tamtych wydarzeń, zwłaszcza Karol Modzelewski, Adam Michnik i Tadeusz Mazowiecki.

Z kolei ustalone na 4 czerwca (wybory do parlamentu) obchody wywołały burzę pośród obozów prezydenckiego, rządowego i solidarnościowego co do ich miejsca i charakteru oraz - oczywiście - zaproszenia uczestników. O jednych zapomniano, innych starano się wyeksponować bez uzasadnienia, bo przecież żyje jeszcze i dobrze pamięta tamte czasy wielu ich (czynnych czy biernych) obserwatorów. Mniejsza o spory między obu warszawskimi pałacami i gdańską kolebka, jako że są one zgodne co do jednego: w 1989 r. pokonano przebrzydłą komunę, choć to pojęcie zrodziło się i zrobiło karierę dopiero po owej dacie (dla mojego pokolenia od czasów dzieciństwa istniała tylko Komuna Paryska!), a nie było żadnego pokonania ale mądre porozumienie sił politycznych, doskonały przykład mądrości rządzących i opozycji, z uznaniem przyjmowane przez zagranicę. ${ }^{8}$ W naszej tradycji historycznej jednak nadal dominują - lansowane przez promotorów tzw. polityki historycznej - kultowe postacie z bro-

\footnotetext{
${ }^{6}$ Tak pisałem w połowie maja 2009 r. czyli w trakcie kampanii do Parlamentu Europejskiego, w której ta partia brała udział. Po jej zakończeniu wiemy jak się zakończyła, a właściwie już wcześniej Lech Wałęsa zorientował się, że wkroczył na zbyt niebezpieczną ścieżkę i ostrożnie się wobec kontrowersyjnego ugrupowania zdystansował, jak mu zarzucano, po zainkasowania wysokiego honorarium.

${ }^{7} \mathrm{Ma}$ ona zresztą swe uzasadnienie, kiedy porównujemy pierwszego przywódcę Solidarności z innymi ludźmi z jego dawnego obozu, zwłaszcza po wyborach prezydenckich z 2005 r. i przypominające Sokolnickiego szafowanie orderami, a także nominacjami wojskowymi dla osób nie żyjących od ponad pół wieku, a nawet z czasów powstania styczniowego. W odniesieniu do Lecha Wałęsy nie brakuje emocjonalnych wypowiedzi nawet ze strony ludzi o przygotowaniu intelektualnym, jak znakomity reżyser Andrzej Wajda, który kiedyś deklarował się zostać jego szoferem, a ostatnio zadeklarował nakręcenie filmu o tej postaci i porównał go - w wywiadzie z Krzysztofem Kwiatkowskim na łamach tygodnika „Newsweek” z 13 III 2011 r., s. 32 nn. - z naczelnikiem Insurekcji 1794 r. (Wałęsa jest Kościuszkq naszych czasów). Jest to zbyt poważna wypowiedź, by historyk na nią nie zareagowal i rezerwuję sobie poświęcenie osobnej uwagi zestawieniu obu tych postaci. Inna sprawa, że przywódca Solidarności zyskuje w opinii publicznej wraz z upływem lat, zwłaszcza w porównaniu z jego dawnymi akolitami, którzy na krótko sprawowali władzę w latach 2005-2007, a w pałacu prezydenckim urzędowali do wiosny $2010 \mathrm{r}$.

${ }^{8}$ Zob. Ku zwycięstwu ,Solidarności”. Korespondencja Ambasady USA w Warszawie z Departamentem Stanu styczeń-wrzesień 1989 („Dokumenty do dziejów PRL”, z. 18, red. serii A. Paczkowski), Przedmowa J. R. Davis Jr., Warszawa 2006.
} 
nią w ręku, związane z przegranymi powstaniami ${ }^{9}$, a nie cieszą się mirem ci, którzy odnosili sukcesy na polu gospodarczym, środkami pokojowymi (Ksawery Drucki-Lubecki, Aleksander Wielopolski).

Kiedy jako świadek i obserwator wydarzeń badacz obserwuje w ostatnim dwudziestoleciu, a więc po zniesieniu cenzury i eksponowanym szumnie „odzyskaniu niepodległości” zamazywanie najnowszej historii ${ }^{10}$, przypomina mi się zdanie zasłyszane $\mathrm{w}$ trakcie polemik z burzliwego roku 1980-1981 na temat naszych wrogów i dobroczyńców z powojennych dziejów: wielu propagandystom wydawało się, że w Jałcie decyzje w sprawach Polski podjęło trzech panów: 1) Josif, 2) Wissarionowicz, 3) Stalin. I wielu było o tym przekonanych, choć ja jako dziecko, przed laty, słuchałem audycji Wolnej Europy o trzech kawalerach jałtańskich - Roosevelcie, Churchillu i oczywiście Stalinie.

$\mathrm{Na}$ tym miejscu odwołam się do wypowiedzi prasowej nestora polskiego dziennikarstwa, Zygmunta Broniarka, który napisał, odwołując się zresztą do wypowiedzi z radiowej dyskusji w dniu 30 kwietnia jednego z opozycjonistów (nazwiska nie podał), który Generałowi nie może nadal wybaczyć wprowadzenia stanu wojennego i zarzekał się, iż pierwszego prezydenta nie znosi, ale mówiąc o obchodach przygotowywanych na 4 czerwca 2009 r. uznat, że Jaruzelski powinien tam być, ponieważ przyczynit się do akceptacji wyników wyborów przez „stronę komunistyczna" "1. Od siebie znakomity publicysta o międzynarodowej renomie dodał, że premier powinien w przepięknych zaproszeniach zwrócić się o przybycie na jubileuszowe spotkanie do absolutnie wszystkich czołowych uczestników wydarzeń sprzed lat dwudziestu.

Po co ten obszerny wstęp z pozoru nie mający nic wspólnego z tematem wystapienia? Ano po to, by zwrócić uwagę na fałszowanie dziejów, które w nowej demokratycznej Polsce wziął na siebie Instytut Pamięci Narodowej, instytucja nawiązująca do ,szczytnych” osiagnnięć propagandy z najgorszego okresu w naszych dziejach powojennych. $Z$ tą różnica, że wówczas nie można było oficjalną drogą z owymi metodami dyskutować, a dzisiaj jest taka możliwość - i miejmy nadzieję, będzie - z nimi prowadzona polemika. Zamykając ową inwokację nawiążę do pojęcia synkretyzm, dobrze znanego w nauce ale obcego propagandzie lub przez nią ignorowanego. Oznacza ono łaczenie $w$ jednq całość różnych, często sprzecznych pogladów filozoficznych, religijnych, społecznych; zespolenie się, skrzyżowanie się jakichkolwiek elementów ${ }^{12}$.

Kwestii tej poświęciłem uwagę $\mathrm{w}$ rozprawce na temat wspomnianego pojęcia w badaniach oraz kulturze politycznej, które zamknąłem następującym zdaniem: Pamiętać [...] nale-

\footnotetext{
${ }^{9}$ Na ten temat szerzej M. Kosman, ,,Determinacja połaczona z rozwagq”. W dziewięćdziesięciolecie Powstania Wielkoplskiego, Poznań 2008; idem, Narodowe powstania w historii i legendzie, „Przegląd Wielkopolski” XXII, Poznań 2008, nr 4(82), s. 5-9.

${ }^{10}$ Zob. ostatnio celne uwagi z okazji dziesięciolecia Instytutu Pamięci Narodowej autorstwa byłego pracownika tej instytucji, aktualnie adiunkta w Instytucie Historii Uniwersytetu Lódzkiego, S. M. Nowinowskiego, Historycy czy architekci politycznej wyobraźni, „Gazeta Wyborcza - Gazeta Świąteczna” z 19-20 III 2011 r., s. 25 n.

${ }^{11}$ Z. Broniarek (z cyklu: „Pikanterie tygodnia”), Pomyst dla premiera Tuska, ,Trybuna”, nr 114 z 16-17 V 2009 r., s. 9.

12 Stownik języka polskiego, pod red. M. Szymczaka, t. III, Warszawa 1983, s. 384. Zob. też W. Kopaliński, Stownik wyrazów obcych i zwrotów obcojęzycznych (wyd. 11), Warszawa 1967, s. 163, por. s. 28 (pojęcie: adaptacja); J. Szczepański, Elementarne pojęcia socjologii, Warszawa 1967, s. 230 n.; Encyklopedia Katolicka KUL, t. 1, Lublin 1985, kol. 79-80.
} 
ży o synkretyzmie w spojrzeniu na dzieje - jeśli nie chcemy patrzeć na nie przez pryzmat uczucia i przy użyciu baśniowych okularów; dalej-o emocjonalnym, czarno-białym stosunku do polityków i przywódców państwowych w narodowej przeszłości-tej tkwiqcej w pomroce źródtowej oraz catkiem nam bliskiej, zwłaszcza dotyczy to tych, którzy mieli odwage podejmowania śmiałych, acz kontrowersyjnych decyzji, daleko wybiegajacych w przyszłość ${ }^{13}$.

Dysponujemy dziś różnymi kompendiami zawierającymi wykaz najważniejszych wydarzeń z najnowszych dziejów Polski. Wydawałoby się, że trudno o bardziej jednoznaczne zestawienia, obiektywne swą zawartością, bo pozbawione subiektywnego elementu oceny. Nic bardziej fałszywego, wystarczy prześledzić owe publikacje by zauważyć, że istnieje tu wdzięczne pole do manipulacji - nadmiernym eksponowaniem jednych, usuwaniem w cień czy zgoła dezawuowaniem innych danych. Na tym miejscu zwrócimy uwagę na synkretystyczny charakter odcinka dziejowego z lat 1981-1989, który dla jednych oznacza czarną dziurę, zaprzepaszczenie przy użyciu siły entuzjazmu szlachetnego wspaniałego narodu, dla innych zaś konsekwentnie realizowaną drogę do pluralizmu ustrojowego, uwieńczoną w dniu wyborów 4 czerwca 1989 r. Owa zmitologizowana data ma charakter emocjonalny, choć niektórzy powtarzają za znaną aktorką, iż wówczas skończył się w Polsce komunizm. Nie skończył się, zresztą w naszym kraju go nie było. Trwała zaś droga do likwidacji quasi-dyktatury, swoistej w polskich warunkach. Droga zaś do przemian ustrojowych od dnia 13 grudnia $1981 \mathrm{r}$. była odgórnie sterowana przy uwzględnianiu sytuacji wewnętrznej w kraju oraz kontekstu międzynarodowego. Sterował nią - oczywiście nie w samotności - doskonały strateg, doświadczony w bojach, który nie chciał porażki, by zasilić szeregi przegranych powstańców... Punkt oparcia dla dalszych wywodów stanowi doskonałe wydawnictwo skromnie zatytułowane Kartki z PRL, przygotowane pod redakcją wytrawnego historyka Wiesława Władyki, którego pierwszy tom obejmuje lata 1944-1970, drugi zaś od stycznia 1971 do grudnia $1989 \mathrm{r}$.

Pod datą 13 grudnia 1981 r. w obszernym haśle poświęconym genezie decyzji podjętej przez ówczesnego premiera czytamy: Wydaje się, że obok kwestii zagrodzenia drogi do współdziałania we władzy Solidarności, najważniejszym zadaniem stanu wojennego nie miało być przeprowadzenie reformy gospodarczej, lecz odbudowanie przy wykorzystaniu sity i prestizu Wojska Polskiego pozycji PZPR. Nigdy w catych dziejach PRL wojsko nie odgrywało tak ważnej roli jak w stanie wojennym, nigdy też tylu wyższych wojskowych nie znalazło się na eksponowanych stanowiskach $w$ administracji państwowej $i$ aparacie partyjnym ${ }^{14}$.

Istotne, że decyzja ta nie zahamowała procesu przemian, a stojący na czele Państwa przywódca patronował konsekwentnie procesowi przemian, również po 4 czerwca - choć wówczas jego rola była zupełnie inna, jednak doniosła - aż do końca swej skróconej prezydentury ${ }^{15}$.

${ }^{13}$ M. Kosman, Synkretyzm w badaniach $i$ w kulturze politycznej, w: Spoleczeństwo, armia i polityka w dziejach Polski i Europy. Studia z dziejów politycznych i wojskowych dedykowane Profesorowi Benonowi Miśkiewiczowi z okazji jubileuszu siedemdziesięciolecia urodzin, Komitet redakcyjny: Antoni Czubiński, Bohdan Lapis, Czesław Łuczak, Poznań 2002, s. 50.

${ }^{14}$ Kartki z PRL. Ludzie, fakty, wydarzenia, pod red. W. Władyki, t. II: 1971 - 1989, Poznań 2006 (dalej cyt.: K II), s. 216.

${ }^{15}$ Znany komentator warszawskiej „Polityki”, wydawcy wspomnianego kompendium, tak ów cytat komentuje: I chyba taka właśnie jest prawda o stanie wojennym: nie chodzito o zagrożenie wojnq domowa, bo takie istniało tylko 
Przed trzema laty minęła 25 rocznica wprowadzenia stanu wojennego, gdy przygotowuję ten tekst znajdujemy się w gorących dniach poprzedzających 20-lecie wyborów z dnia 4 czerwca 1989 r. Dla historyka wprawdzie jest to czas niezbyt odległy i podlegający solennym ocenom propagandowym, wystarczający jednak, by podjąć się oceny manipulacji faktografią, którą ocenia jako bezceremonialną, również nie bez udziału osób mieniących się profesjonalnymi badaczami. Tych nigdy nie brakowało u stóp aktualnych władz, a tym bardziej bywali gorliwi, w im większym stopniu usiłowali zapomnieć o własnej przeszłości. Tymczasem obok klasycznych źródeł dysponujemy również własnymi obserwacjami, szczególnie cennymi, choć nie należy zapominać o subiektywizmie ocen a także o wybiórczym manipulowaniu materiałami oraz o ich preparowaniu przez propagandystów.

Dla podpisanego jako świadka epoki ale przede wszystkim badacza posiadającego doświadczenie w penetrowaniu bardziej odległych epok zasadnicze znaczenie miało podjęte zaraz po 1989 r. tworzenie fałszywego obrazu niedawnej przeszłości, bajecznego, przeciwstawiającego sobie dwa skrajne obozy, czarny nazwany „komuną” (do jednego worka wrzucano całą powojenną przeszłość) oraz wyidealizowany, w niewinnej bieli. Dziś bohaterowie po obu stronach, zwłaszcza tej zwycięskiej, która stworzyła wizję rozgromienia w owym roku zbrodniczej komuny, nie wytrzymali próby czasy, łącznie ze sztandarową postacią tego, który - jak głosi - obalił komunizm. Obserwując działania propagandystów i tworzenie nowego obrazu najnowszych dziejów, a zwłaszcza koncentrowanie się przy atakach na jedną z głównych postaci 13 grudnia (oczywiście w piekielnych barwach) przy zapominaniu o jego roli w przemianach uwieńczonych 4 czerwca, zdecydowałem się odejść na jakiś czas od zaplanowanych tematów i zająć się biografią polityczną Wojciecha Jaruzelskiego. Efektem tego obok szeregu artykułów stały się dwie książki.

Na tym miejscu chciałbym opowiedzieć się z całą mocą za synkretystycznym charakterem przemian ustrojowych, sterowanych przez tego najwybitniejszego z przywódców państwowych Polski okresu 1945-1989/90 i odrzucić zarzuty o stagnacji, a także zauważyć, że uratował on kraj przed przelewem krwi, do którego doprowadziłaby rewolucja czy powstanie. A to groziło nieuchronnie wskutek interwencji zewnętrznej, dla której alternatywę stanowiłaby jedynie przeprowadzona przez Kreml wymiana kadry kierowniczej w Warszawie.

Ewolucja, która doprowadziła do pluralizmu ustrojowego, przebiegała w ramach trzech etapów. Pierwszy obejmował czas do formalnego zniesienia po 586 dniach stanu wojennego (22 lipca 1983 r.), drugi wiązałbym z kontynuacją premierostwa Wojciecha Jaruzelskiego (do 25 IX 1985), trzeci rozpoczął się wraz z jego rezygnacją z bezpośredniego kierowania rządem i przejęciem funkcji formalnej głowy Państwa (połączonej w dalszym ciągu ze sprawowaniem władzy realnej jako I sekretarza KC PZPR, co było w ówczesnych warunkach zupełnie zrozumiałe. Etap ten miał trwać niemal cztery lata, jeśli nie liczyć nadto półtorarocznej prezydentury, sprawowanej w zupełnie innych niż uprzednio warunkach. Ale owe niemal osiemnaście miesięcy miały znaczenie dla procesu ewolucyjnego przekazywania władzy.

\footnotetext{
w propagandzie PZPR, ani o pogróżki ze strony Moskwy, bo wciqż nie ma dowodów, że Rosjanie szykowali zbrojnq interwencję. Chodziło o odzyskanie monopolu władzy i kontroli przez partię komunistycznq. W tym sensie stan wojenny by aktem kontrrewolucji i restauracji osłabionego reżimu wbrew aspiracjom i dqżeniom znacznej części społeczeństwa. Osiem lat później ocalona przemoca Polska Ludowa przestała istnieć (A. Szostkiewicz, Wzloty i upadki. II tom ,, Kartek z PRL” dokumentuje emancypację społeczeństwa od komunizmu, „Polityka”, nr 1(2586) z 6 I 2007 r., s. 91). Nie tu miejsce na polemikę z powierzchowną oceną sytuacji, z którą trudno się zgodzić. Naszym tematem są wydarzenia z owego ośmiolecia, o którym mowa w ostatnim zdaniu artykułu Szostkiewicza.
} 
Oczywiście Jaruzelski nie działał w samotności, ogromną rolę w procesie przemian odegrała mądra (podkreślam znaczenie tego słowa) opozycja oraz mediacyjna postawa Kościoła. Generał zdołał pozyskać do współpracy lojalną wobec niego grupę współpracowników, zwolenników synkretystycznych metod w przeobrażeniach ustrojowych, ludzi w mundurach (generałowie Kiszczak, Janiszewski, Siwicki i in.) oraz w cywilu (Rakowski, Ciosek, Urban, wierny u boku Wiesław Górnicki, który siebie sam nazwał „kulawym Szerpą). Cechował ich realizm, metody pozytywistyczne i odrzucanie - przy całym szacunku dla nich - wizji romantycznych. WJ nie miał ochoty na powtórzenie koszmaru syberyjskiego. Brał pod uwagę kontekst międzynarodowy, przede wszystkim układ sił na Kremlu. A tu realna zmiana dokonała się dopiero po śmierci ostatniego ze starców, Konstantina Czernienki i dojściu do władzy w dniu 11 marca 1985 r. Michaiła Gorbaczowa. A ten początkowo z pewną rezerwą spoglądał na Warszawę, zanim odżegnał się od mieszania w wewnętrzne sprawy sojuszników z Układu Warszawskiego.

Nie wykluczone, że pewna zwłoka była tu kwestią taktyki, choć ta nie stanowiła mocnej strony w osobowości tego wizjonera i stratega wielkiej miary. Ale nie należy traktować jako przypadek to, że Jaruzelski postanowił skupić się na pracach koncepcyjnych jako przewodniczący Rady Państwa, co nastąpiło pół roku po zmianach na Kremlu.

Pierwszy z wyłonionych trzech etapów to czas konfrontacji, przy czym Generał udowodnił wówczas, że nie jest polskim Pinochetem, co nie oznacza, że takim go czyniła propaganda podziemna, w co na początku bodaj była skłonna wierzyć nawet paryska „Kultura”. Zarazem doszło do nawiązania kontaktów i - nie waham się tego powiedzieć - współpracy z prymasem Glempem oraz dyskretnego porozumienia z papieżem Janem Pawłem II, które przetrwało nawet czasy prezydentury Wojciecha Jaruzelskiego.

Nadeszły czasy sławetnych reform gospodarczych, rozłożonych na trzy etapy. Tutaj odpowiedzialnością obdarzano niezbyt udanego premiera Zbigniewa Messnera. Ale trzeba pamiętać o obstrukcji opozycyjnej, o nawoływaniu Wałęsy poprzez Wolną Europę, by robotnicy pracowali tempie żółwia, o narodowych cechach Polaków. Od WJ oczekiwano, by nie stosując metod chlijskiego dyktatora dokonał cudu w gospodarce, jako że ...dysponował pełnią władzy, miał pod swą komendą armię. Znowu oczekiwanie jak z bajki.

Równolegle z represjami podejmowano kroki w kierunku demokratyzacji, których skutki okazały się dalekosiężne i trwałe.

Dnia 29 maja 1985 r. sejm uchwalił ustawę o Trybunale Konstytucyjnym, zapowiedzianym już trzy lata wcześniej (a więc w ,mrocznych dniach stanu wojennego”) w noweli konstytucyjnej z marca 1982 r. Do jego kompetencji należało badanie zgodności z ustawą zasadniczą ustaw i innych aktów prawnych. W Polsce międzywojennej nie zdecydowano się na wprowadzenie sądownictwa konstytucyjnego, TK w pełni się zdynamizował dopiero po 1989 r., ale grunt pod jego niczym nie ograniczoną działalność został stworzony kilka lat wcześniej.

Obok Trybunału Konstytucyjnego zaczął odgrywać rolę mający międzywojenne tradycje Trybunał Stanu, inaugurując działalność oskarżeniem byłego premiera Piotra Jaroszewicza.

Dnia 15 lipca 1987 r. sejm przyjął ustawę o Rzeczniku Praw Obywatelskich, którego zadaniem było badanie zarzutów wskazujacych na naruszenie praw i wolności obywatelskich ${ }^{16}$. W listopadzie Sejm powołał na to stanowisko prof. Ewę Łętowską, która wykazała się energią, rozsądkiem, odwagą i pełnymi kompetencjami, podobnie jak jej następcy w kolejnych kadencjach, profesorowie Tadeusz Zieliński, Zygmunt Zieliński i Andrzej Zoll. Trudno

\footnotetext{
${ }^{16}$ Kartki II, s. 289.
} 
byłoby tę opinię powtórzyć w odniesieniu do pełniącego po upływie kadencji tego ostatniego, tę funkcję dra Janusza Kochanowskiego, który zginął w katastrofie samolotowej pod Smoleńskiem w dniu 10 kwietnia 2010 r.

Opozycja już na dwa lata przed pamiętnymi wyborami z dnia 4 czerwca 1989 r. powoli przygotowywała się do stworzenia sui generis gabinetu cieni, jako pierwszy krok w tym kierunku należy potraktować powołanie w dniu 3 kwietnia 1987 r. eksperckiego komitetu przy Lechu Wałęsie ${ }^{17}$. Kontrolując - co było ważne niezmiernie w silnych nastrojach antyradzieckich - propagandowy wydźwięk stosunków z Kremlem ekipa Jaruzelskiego rozważnie stawiała w obustronnych kontaktach kwestie ,zaszłości” historycznych - dnia 14 kwietnia 1985 r. została udostępniona we Wrocławiu po latach ukrycia Panorama Racławicka Wojciecha Kossaka i Jana Styki ${ }^{18}$; 21 kwietnia 1987 r. obaj przywódcy podpisali na Kremlu deklarację o współpracy w dziedzinie ideologii, nauki i kultury, czego efektem stały się prace nad usuwaniem „,białych plam” ze wzajemnej przeszłości ${ }^{19}$. Najtrudniejszą była sprawa Katynia, ale i tu przed końcem prezydentury WJ wymógł na prezydencie ZSRR ogłoszenie stosownej deklaracji, złożył wizytę przy grobach pomordowanych rodaków (jej bogata dokumentacja fotograficzna nie doczekała się rozpowszechnienia po jego ustąpieniu ze stanowiska); nie przeszkodziło to ich następcom, Jelcynowi i Wałęsie, przypisać sobie stosownych zasług i zarzucać poprzednikom, jakoby zarzucili starania o ujawnienie prawdy ${ }^{20}$.

Przełomowe znaczenie w kierunku ostatecznego sfinalizowania procesu przemian miało rozpoczęcie obrad Rady Konsultacyjnej przy przewodniczącym Rady Państwa w dniu 6 grudnia 1986 r. ${ }^{21}$ Jej obrady trwały do późnej wiosny 1989 r. i miały przełomowe znaczenie w zbliżeniu racji strony rządowej i opozycji, przebieg spotkań dokumentują dwa obszerne tomy protokołów obrad. Dnia 13 czerwca 1988 r. w referacie wygłoszonym przez WJ na VII plenum KC PZPR znalazło się określenie „okrąły stół”22, 16 stycznia następnego roku rozpoczęły się w dramatycznej atmosferze obrady drugiej części X plenum, które - pod presją ustapienia WJ, a wraz z nim Kiszczaka, Siwickiego i premiera Rakowskiego - otworzyły drogę do legalizacji „Solidarności”; 27 I w Magdalence ustalono szczegóły związane z rozpoczęciem obrad „okrąłłego stołu” ${ }^{\text {,23 }}$, które nastąpiło w Pałacu Rady Ministrów 6 lutego a zakończyło 5 kwietnia.

Odtąd wydarzenia potoczyły się lawinowo, co nie oznacza, że bez zgrzytów - również w opozycyjnym obozie (np. zarzuty wobec Siły-Nowickiego za udział w RK). O „błędach historii” pisał premier Mieczysław Rakowski w liście do 98-letniego gen. Stanisława Maczka), 8 V ukazał się pierwszy numer „Gazety Wyborczej”.

Klimat ówczesnych kontaktów dyplomatycznych, atmosfery wokół polityki Wojciecha Jaruzelskiego, doskonale dokumentują materiały strony kościelnej (oczywiście nie eksponujące przebiegu najbardziej tajnych rozmów), a zwłaszcza opublikowana przed kilku laty przez Instytut Studiów Politycznych PAN (też nie w całości!) korespondencja dyplomatów USA z Departamentem Stanu ${ }^{24}$.

${ }^{17}$ Kartki II, s. 288.

${ }^{18}$ Kartki II, s, s.265.

${ }^{19}$ Ibidem, s. 286.

${ }^{20}$ Szerzej M. Kosman, Los Generała (aneks).

${ }^{21}$ Kartki II, s. 282.

22 Ibidem, s. 301.

${ }^{23}$ Ibidem, s. 309.

${ }^{24}$ Ku zwycięstwu ,Solidarności.” Korespondencja Ambasady USA w Warszawie z Departamentem Stanu styczeń-wrzesień 1989, Przedmowa J. R. Davies jr., wstęp G. F. Domber, opracowanie G. F. Domber, M. Jastrząb, A. Paczkowski, P. Sowiński, Warszawa 2006. 
Podczas wizyty w Polsce prezydenta USA - miała ona miejsce w dniu 10 lipca 1989 r. - George Bush senior w trakcie kolacji wydanej na jego cześć przez polskiego przywódcę dwukrotnie podnióst zastugi WJ w dziele przekształcenia PRL w państwo demokratyczne ${ }^{25}$.

A w dziesięć lat później Wojciech Jaruzelski tak zaczyna kolejną swą publikację na temat stanu wojennego i jego konsekwencji: Wkrótce kolejna rocznica wprowadzenia stanu wojennego. Znów pojawiq się zwiqzane z niq refleksje i emocje. Tych ostatnich będzie jak zwykle więcej. Już widzę dominujacy w mass mediach horror - czotgi, patki, armatki wodne. Ukaża się kolejne wspomnienia, oskarżenia, wezwania do rozliczeń i rozrachunków. Pod moimi oknami odprawione zostana ,,misteria” przez grupki aktywistów Ligi Republikańskiej oraz $K P N$. Nie zaniechano ich nawet wówczas, gdy ciężko chory przebywałem w szpitalu ${ }^{26}$.

Ale - choć sceneria pozostała i w następnych latach podobna - mimo nasilenia natrętnej propagandy powoli przebijają się głosy autentycznych dawnych opozycjonistów, pod oknami Generała w grudniową noc pojawiają się również kontrmanifestacje, ukazują się wspomnienia ludzi autentycznie zaangażowanych po $1980 \mathrm{r}$. w proces przemian ustrojowych. Prawda, że dominuje nad nimi hałas propagandowy, ale gutta cavat lapisem - kropla drąży skałę...

Jedna z dalszych wypowiedzi byłego Prezydenta, z 2006 r., nosi tytuł: Historia nie powinna dzielić (Toruń 2006). Dziś nękany ustawicznymi wizytami szpitalnymi i operacjami sędziwy przywódca, który stał się wytrawnym pisarzem politycznym, spędza mnóstwo czasu na ławie oskarżonych w politycznych procesach ${ }^{27}$, zamiast odbierać od następców ${ }^{28}$ wyrazy uznania za mądre przeprowadzenie kraju od ustroju totalitarnego do demokracji. Przełom w tym zakresie możemy obserwować po wyborze na prezydenta Rzeczypospolitej w połowie 2010 r. Bronisława Komorowskiego, co jednak spotyka się z napastliwą reakcją ze strony tzw. prawicowej opozycji ${ }^{29}$.

\section{Summary}

The paper concerns the syncretistic, evolutionary nature of political transformation in Poland prior to the introduction of political plurality in mid-1989. The author refers to the studies published in his books: Wojciech Jaruzelski wobec wyzwań swoich czasów [Wojciech Jaruzelski and the challenges of his time] (2003) and Los generata [The General's fate] (2008) where he confronts recorded facts with political propaganda.

The evolution which eventually led to political plurality occurred in three stages. The first spanned the period ending when martial law was formally revoked after 586 days (on July 22, 1983), the second one was related to the office of Prime Minister that Wojciech Jaruzelski

${ }^{25}$ M. F. Rakowski, Dzienniki polityczne, t. X, Warszawa 2005, s. 472.

${ }^{26}$ W. Jaruzelski, Różnić się mądrze. Jak doszło do stanu wojennego, Warszawa 1989, s. 5 n.

${ }^{27}$ Stąd sala sądowa stała się miejscem składania wyrazów uznania sędziwemu mężowi stanu przy takich okazjach, jak jego 86 urodziny czy dwudziestolecie pluralizmu ustrojowego w Polsce (w tym momencie aktualny premier organizował obchody z udziałem zagranicznych gości na Wawelu a urzędujący prezydent - w Gdańsku).

${ }^{28}$ W Pałacu Prezydenckim jedynie ówczesny następca (był nim Aleksander Kwaśniewski) zorganizował uroczyste spotkanie ze swym poprzednikiem w 80. rocznicę urodzin Wojciecha Jaruzelskiego (lipiec 2003 r.) Zostało ono jednak, podobnie jak sam jubileusz, pominięte milczeniem przez mass-media z wyjątkiem kilku lewicowych i kombatanckich gazet, choć prasa, radio i telewizja nie szczędziły miejsca relacjom z fet rocznicowych Lecha Wałęsy czy prałata Henryka Jankowskiego.

${ }^{29}$ Szerzej na ten temat M. Kosman, Gdzie jest Generat? Nad medialnym wizerunkiem Wojciecha Jaruzelskiego, w: Media Dawne i Współczesne, pod red. B. Kosmanowej, t. V, Poznań 2010. 
held (until September 25, 1985), and the third stage commenced when he gave up direct supervision of the government and assumed the office of Head of State (which continued to be combined with the actual power he held as $1^{\text {st }}$ secretary of the Central Committee of the Polish United Workers' Party (KC PZPR)). The last stage was to continue for nearly four years, excluding over 18 months of his presidency, held under completely different conditions. Yet these 18 months were significant for the evolutionary process of the handover of power. Jaruzelski took into consideration the international context, particularly the balance of power in the Kremlin. Real change took place there only after Mikhail Gorbachev assumed power on March 11, 1985.

On May 29, 1985 the Polish parliament passed the law on the Constitutional Tribunal, announced three years earlier in an amendment to the Constitution of March 1982. On July 15, 1987 the parliament passed the law on the Defense of Human Rights. The State Tribunal began working at the same time. The first president of Poland after the transformation drew attention to these facts a few years later. The ex-President has become a skilful polemicist and political writer, documenting the peaceful political transformation in Poland after 1980. 